\section{Planting Date, In-ground Time Affect Cut Flowers of Acidanthera, Anemone, Allium, Brodiaea, and Crocosmia}

\author{
A.M. Armitage and J.M. Laushman \\ Department of Horticulture, University of Georgia, Athens, GA 30602
}

Additional index words. Abyssinian gladiolus, Acidanthera murielae, poppy anemone, Anemone coronaria, brodea, Brodiaea laxa, drumstick chives, Allium sphaerocephalum, Montbretia, Crocosmia crocosmiiflora, longevity, harvest distribution, duration of growth

Abstract. Various bulbous species were planted during the fall and winter in an attempt to extend harvest periods of cut flowers. In the first year, late planting resulted in later flowering, but shorter stems and reduced yield than early planting; however, some responses were species specific. No differences in flowering due to initial planting times occurred in the subsequent 2 years, regardless of species tested. Anemone coronaria L. and Acidanthera murielae Hoog. ex Perry were productive for 1 year only, but Allium sphaerocephalum L., Brodiaea laxa Wats., and Crocosmia $\times$ crocosmiiflora (V.Lem. ex E. Morr.) N.E. Br. were productive for 2 to 3 years. The peak harvest for anemones was 3 to 5 weeks from beginning of harvest, depending on cultivar, and 10 to 20 days from beginning of harvest for crocosmia. Anemone 'Mona Lisa' produced longer stems and larger flowers and flowered earlier than 'De Caen'.
Flowers of bulbous crops are produced for cut flowers in the greenhouse or field in many countries. Crops such as lilies (Lilium L.), tulips (Tulipa L.), Dutch iris (I. $\times$ hollandica), daffodils (Narcissus L.), and anemone (Anenome coronaria L.) are usually forced under protected structures, such as greenhouses or cold frames. However, Dutch iris, tuberose (Polianthes tuberosa L.), liatris [Liatris spicata (L.) Wind.], ornamental onions (Allium L.), and numerous other species are also forced in the field under minimal in the field are limited by the natural climatic conditions under which they grow (Armitage, 1987), and control of flowering time is minimal. In most bulbous crops, flowering is genetically programmed to occur at certain times of the year, depending on environmental conditions (Rees, 1972).

The United States and Canada have recently been divided into 11 hardiness zones (U.S. Dept. 'of Agriculture, 1990) and attempts have been made to assign perennial species to cold hardiness zones (Taylor, 1961; Wyman, 1971). The hardiness zone system, although far from perfect, provides low-temperature limits to perenniality for many species.

An additional limitation to commercial production of cut flowers of many bulbous

Received for publication 13 Mar. 1989. We thank Rosemary Scully Key, Anita Harris, and Henaege Tseng for their assistance. Special thanks to $\mathrm{M}$. Van Waveren and Sons, Mt. Airy, N. C., for donation of the bulbs and to Yoder Bros., Astubula, Ohio, for financial support of the work. The cost of publishing this paper was defrayed in part by the payment of page charges. Under postal regulations, this paper therefore must be hereby marked advertisement solely to indicate this fact. protection (De Hertogh, 1989). Crops forced species is the short flowering time. If natural flowering time could be extended over several weeks or months, the use of bulbous species for field-grown cut-flower produc- tion would be more practical. Tompsett (1980) demonstrated that in-ground defoliation of Narcissus tazetta 'Grande Soleil d'Or' by burning the soil surface several times advanced flowering by 14 to 20 days. However, covering the soil with clear polyethylene during the summer retarded flowering. Most practices for accelerating daffodil flowering rely on heat treatments of 30 to $40 \mathrm{C}$ for several days after bulbs are dug, depending on species and cultivar (Rees, 1985a, 1985b). The flowering period may be extended by delayed planting and longer preplant storage treatments. Later field planting dates (December through February) for fall-planted species are practical in the southern United States where snow cover is minimal and soil temperatures are cold enough to initiate stem elongation. Regional information on minor cut-flower crops such as Allium, Brodiaea, and Anemone has been published (De Hertogh, 1989) but few other data (Armitage, 1987) are available concerning yield, planting time, and effects of longevity on yield and flower quality.

The objective of this work was to determine: i) if time to flower and duration of flowering of bulbous species could be extended by delayed planting; ii) if the same response would be repeated the second year for plants that remained in the ground; iii) if bulbous species should be treated as perennial, biennial, or annual crops; and iv) what yield, flower and stem quality are to be ex-

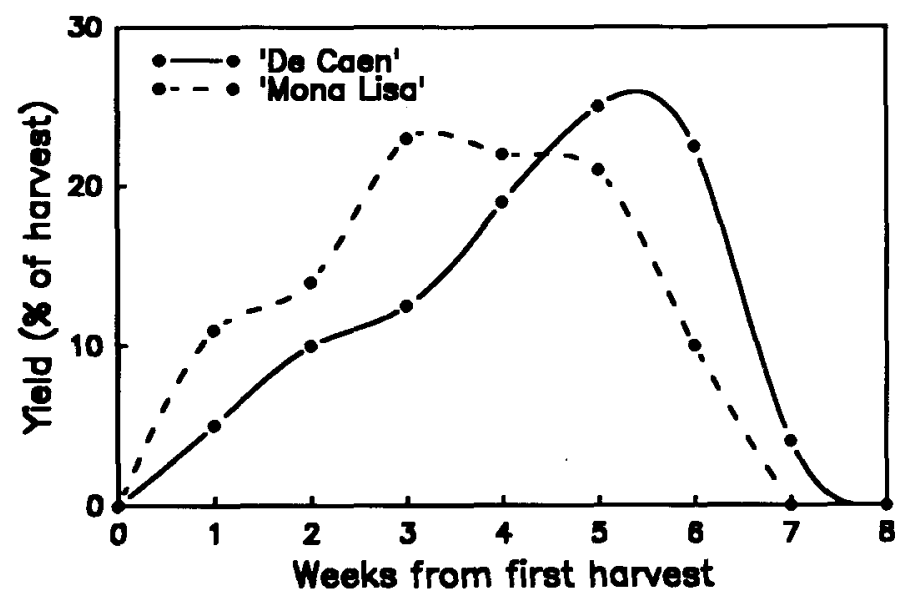

Fig. 1. Weekly distribution of flower harvest for Anemone coronaria 'De Caen' and 'Mona Lisa'.

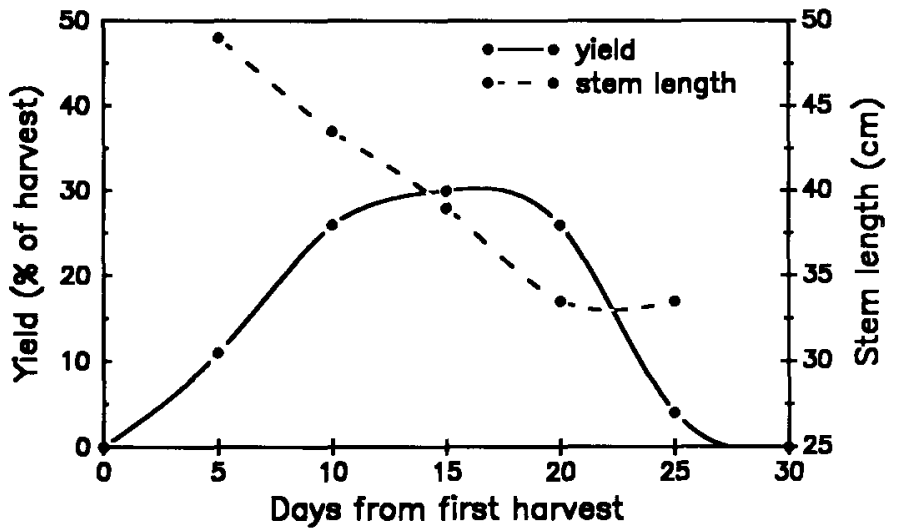

Fig. 2. Distribution of yield and stem length of Crocosmia $\times$ crocosmiiflora 'James Coey' in relation to harvest (1987). 
Table 1. Species and planting dates used in planting time study. Sample size $=99$.

\begin{tabular}{|c|c|c|c|c|c|c|c|}
\hline \multirow{2}{*}{$\begin{array}{l}\text { Botanical name } \\
\text { (circumference, cm) }\end{array}$} & \multirow[b]{2}{*}{ Common name } & \multirow{2}{*}{$\begin{array}{l}\text { Spacing } \\
(\mathrm{cm})\end{array}$} & \multicolumn{5}{|c|}{ Month planted $^{2}$} \\
\hline & & & Nov. & Dec. & Jan. & Feb. & Mar. \\
\hline $\begin{array}{l}\text { Acidanthera murielae } \\
\quad(8-10)\end{array}$ & $\begin{array}{l}\text { Abyssinian } \\
\text { gladiolus }\end{array}$ & 7.5 & $\sqrt{ }$ & & & $\checkmark$ & $\sqrt{ }$ \\
\hline $\begin{array}{l}\text { Allum sphaerocephalum } \\
\text { (5) }\end{array}$ & Drumstick chives & 2.5 & $\sqrt{ }$ & $\sqrt{ }$ & & & \\
\hline $\begin{array}{l}\text { Anemone coronaria } \\
(5-6)\end{array}$ & Poppy anemone & 2.5 & $\sqrt{ }$ & $\sqrt{ }$ & $\checkmark$ & $\checkmark$ & \\
\hline $\begin{array}{l}\text { Brodiaea laxa Wats. } \\
\text { Queen Fabiola } \\
\text { (5) }\end{array}$ & Brodea & 5 & $\checkmark$ & $\checkmark$ & $\sqrt{ }$ & $\checkmark$ & \\
\hline $\begin{array}{l}\text { Crocosmia } \mathrm{x} \\
\text { crocosmuiflora } \\
\text { James Coey } \\
\text { (5) }\end{array}$ & Montbretia & 5 & & & $\sqrt{ }$ & $\checkmark$ & $\checkmark$ \\
\hline
\end{tabular}

${ }^{2}$ Actual planting dates 15 Nov., 18 Dec., 3 Jan., 19 Feb., 31 Mar.

Table 2. The effect of planting dates on 1st year harvest (1986) of field-grown bulbous crops.

\begin{tabular}{|c|c|c|c|c|c|c|}
\hline $\begin{array}{l}\text { Month of } \\
\text { planting }\end{array}$ & $\begin{array}{c}\text { Survival } \\
(\%)\end{array}$ & $\begin{array}{c}\text { Yield } \\
\text { (flowers/plant) }\end{array}$ & $\begin{array}{c}\text { First } \\
\text { harvest } \\
\text { (date) }\end{array}$ & $\begin{array}{c}\text { Harvest } \\
\text { duration } \\
\text { (days) }\end{array}$ & $\begin{array}{l}\text { Stem } \\
\text { length } \\
(\mathrm{cm})\end{array}$ & $\begin{array}{c}\text { Stem } \\
\text { diameter } \\
(\mathrm{mm})\end{array}$ \\
\hline \multicolumn{7}{|c|}{ Acidanthera murieliae } \\
\hline November & $98 \mathrm{a}^{2}$ & $1.2 \mathrm{a}$ & 2 July & $20 \mathrm{a}$ & $72.3 \mathrm{a}$ & $8.2 \mathrm{a}$ \\
\hline Fe bruary & $97 \mathrm{a}$ & $1.3 \mathrm{a}$ & 2 July & $26 \mathrm{a}$ & $70.8 \mathrm{a}$ & $8.5 \mathrm{a}$ \\
\hline March & $84 b$ & $0.8 \mathrm{a}$ & 11 July & $21 \mathrm{a}$ & $70.2 \mathrm{a}$ & $7.7 \mathrm{a}$ \\
\hline \multicolumn{7}{|c|}{ Anemone coronaria De Caen } \\
\hline November & $96 \mathrm{a}$ & $10.2 \mathrm{a}$ & 27 Feb. & $65 \mathrm{a}$ & $23.6 \mathrm{a}$ & $4.5 \mathrm{a}$ \\
\hline December & 89 a & $4.8 \mathrm{~b}$ & 30 Mar. & $33 \mathrm{~b}$ & $18.9 \mathrm{a}$ & $4.4 \mathrm{a}$ \\
\hline January & $25 \mathrm{~b}$ & $1.1 \mathrm{c}$ & 15 Apr. & $17 \mathrm{C}$ & $13.9 \mathrm{~b}$ & $3.9 \mathrm{~b}$ \\
\hline February & $20 \mathrm{~b}$ & $0.2 \mathrm{c}$ & 30 Apr. & $5 \mathrm{~d}$ & $14.0 \mathrm{~b}$ & $3.8 \mathrm{~b}$ \\
\hline \multicolumn{7}{|c|}{ Brodiaea laxa Queen Fabiola } \\
\hline November & $98 \mathrm{a}$ & $0.8 \mathrm{~b}$ & 27 May & $7 \mathrm{~b}$ & $21.7 \mathrm{~b}$ & $4.7 \mathrm{a}$ \\
\hline December & $98 \mathrm{a}$ & $1.4 \mathrm{a}$ & 21 May & $13 \mathrm{a}$ & $30.1 \mathrm{a}$ & $3.9 \mathrm{ab}$ \\
\hline January & $98 \mathrm{a}$ & $1.0 \mathrm{ab}$ & 29 May & $8 \mathrm{~b}$ & $24.8 \mathrm{ab}$ & $2.7 \mathrm{~b}$ \\
\hline February & 98 a & $1.3 \mathrm{a}$ & 27 May & $13 \mathrm{a}$ & $29.3 \mathrm{a}$ & $3.1 \mathrm{~b}$ \\
\hline \multicolumn{7}{|c|}{ Crocosmia $\times$ crocosmiiflora James Coey } \\
\hline January & $100 \mathrm{a}$ & $1.3 \mathrm{a}$ & 2 July & $30 \mathrm{a}$ & $64.3 \mathrm{a}$ & $5.0 \mathrm{a}$ \\
\hline February & $100 \mathrm{a}$ & $0.8 \mathrm{~b}$ & 15 July & $25 \mathrm{ab}$ & $50.5 \mathrm{~b}$ & $4.8 \mathrm{a}$ \\
\hline March & $100 \mathrm{a}$ & $0.8 \mathrm{~b}$ & 21 July & $21 \mathrm{~b}$ & $50.0 \mathrm{~b}$ & $4.6 \mathrm{~b}$ \\
\hline
\end{tabular}

${ }^{2}$ Means within species and columns followed by the same letter are not significantly different using Tukey's HSD test, $P=0.05$.

pected from field-grown bulbous species in U.S. Dept. of Agriculture revised' climatic zone 7.

Raised beds were constructed in 1985. Composted equine manure was incorporated into the natural Cecil clay loam soils and the beds were filled 0.6 to $0.8 \mathrm{~m}$ deep with the compost-clay mixture. The beds were exposed to full sun and irrigated overhead when necessary. The depth of planting of all bulbous roots was about three times their diameter. Corms (Acidanthera, Brodiaea, and Crocosmia), tubers (Anemone), and bulbs (Allium) were received, planted, and spaced as in Table 1. Bulbous roots were planted in three replicates per planting date in a completely randomized design. All species were stored at 18 to $22 \mathrm{C}$ at a commercial facility in Mt. Airy, N. C., until shipped to our laboratory. No sprouting was apparent on any species at any planting date. All species were planted within 4 days of their receipt at the Univ. of Georgia $\left(34^{\circ} \mathrm{N}\right.$ latitude, revised cold hardiness zone 7). No pesticides were applied to any crop, and a single sidedressing of $\mathrm{KNO}_{3}$ was applied on emergence. For Anemone coronaria, a cultivar trial with 'De
Caen' and 'Mona Lisa' also was conducted in 1987-88. For this test, 2-year-old tubers (5 to $6 \mathrm{~cm}$ diameter), received form PanAmerican Plant Co. (Chicago), were planted in Nov. 1987.

Flowers were initially harvested during the 1986 growing season. The date of first harvest was the date of first anthesis. Plants remained in the ground and flowers were harvested again in 1987 and 1988. Upon harvest, harvest duration (time between first and last harvest), stem length, stem diameter, and flower diameter (depending on species) were recorded. Analysis of variance and Tukey's test for differences between means were conducted where appropriate.

Although significant differences in various characteristics occurred in several species due to planting times the first year, 1985 planting dates had no significant effect in subsequent years (data not shown). Therefore, stems harvested in 1987 and 1988 were pooled for all 1985 planting dates.

Acidanthera. Planting time had no significant effect on flower yield, although fewer late-planted corms sprouted as a result of the late plantings (Table 2). The first harvest date was later for late-planted corms, but harvest duration was not extended due to planting times (Table 2). No other differences due to planting date occurred. In revised climatic zones 7 through 9, November to February plantings would be acceptable, but plantings later than February should be avoided. Yields in 1987 and 1988 were significantly reduced compared with those of 1986 (Table 3). Numerous offsets were formed after flowering, and foliage was produced at the expense of flower production. These data suggest that Acidanthera should be treated as an annual in revised climatic zone 7 . Since corms are winter hardy only to zone 8 [(Taylor, 1961), revised zone 7 (1990)] and must be lifted, divided, and stored if planted further north, they should be treated as an annual throughout the United States. Stem length and diameter also declined after 1986 (Table 3), further suggesting that this species should be replanted each year even in areas where bulbs overwinter in the ground.

Anemone. Yield, harvest duration, stem length, and flower diameter were significantly lower for January and February plantings than for those in November and December (Table 2). The date of first harvest was extended with each later planting (Table 2 ), but the reduction in duration of harvest and yield offset any potential benefits of a later harvest date. Anemones are produced in greenhouses under cool conditions, and quality and yield decline as temperatures rise (Gill, 1979; Horovitz, 1985). The short harvest duration on plantings from December through February suggests that relatively high temperatures in the field also resulted in a decline in flower production. Yield and harvest duration significantly declined after the November planting. In England, marketable yield and stem length of 'San Piran' anemones declined when planting was deferred from May to July (Horovitz, 1985). The decline in yield due to late planting dates in our study was not only attributable to rising temperatures after sprouting but also to lack of sufficient vernalization and increased pathogen activity, which resulted in poor tuber survival (Table 2). Maia and Vernard (1974) found that the threshold cold requirement for 'Wicabri' anemones was 4 weeks at 1C. They also suggested that high temperatures after planting resulted in devernalization of the tubers. Although 'De Caen' is less responsive than 'Wicabri' to vernalization (Horovitz, 1985), inadequate exposure to cold followed by relatively high temperatures likely resulted in the poor yields in later plantings.

Tuber survival fell significantly from $90 \%$ in 1985 to $30 \%$ and $20 \%$ in 1986 and 1987 , respectively, although stem length and yield per surviving tuber were not affected (Table 3 ). The resulting reduction in tuber survival also suggests that anemone should be treated as an annual in revised climatic zone 7 . Tuber decline between 1985 and 1987 was likely due to warm summers and not winter injury, as $A$. coronaria is winter hardy to zone 5 (Taylor, 1961) and the beds were raised and well-drained.

Yields for 'Mona Lisa' and 'De Caen' were 
Table 3. Yield and stem quality of bulbous species over 3 years.

\begin{tabular}{|c|c|c|c|}
\hline Year & $\begin{array}{c}\text { Yield } \\
\text { (stems/bulb) }\end{array}$ & $\begin{array}{c}\text { Stem } \\
\text { length } \\
(\mathrm{cm})\end{array}$ & $\begin{array}{c}\text { Stem } \\
\text { diameter } \\
(\mathrm{mm})\end{array}$ \\
\hline \multicolumn{4}{|c|}{ Acidanthera murielae } \\
\hline 1986 & $1.2 \mathrm{a}^{2}$ & $71.5 \mathrm{~b}$ & $8.0 \mathrm{~b}$ \\
\hline 1987 & $0.6 \mathrm{~b}$ & 80.5 a & $7.5 \mathrm{a}$ \\
\hline 1988 & $0.5 \mathrm{~b}$ & $81.6 \mathrm{a}$ & $7.5 \mathrm{a}$ \\
\hline \multicolumn{4}{|c|}{ Anemone coronaria $\mathrm{De}$ Caen } \\
\hline 1985 & $6.5 \mathrm{a}$ & $25.3 \mathrm{a}$ & $4.5 \mathrm{a}$ \\
\hline 1986 & $7.0 \mathrm{a}$ & $23.4 \mathrm{a}$ & $4.3 \mathrm{a}$ \\
\hline 1987 & $5.4 \mathrm{~b}$ & $21.1 \mathrm{a}$ & $4.5 \mathrm{a}$ \\
\hline \multicolumn{4}{|c|}{ Allium sphaerocephalum } \\
\hline 1986 & $1.2 \mathrm{~b}$ & $67.5 \mathrm{a}$ & $6.8 \mathrm{a}$ \\
\hline 1987 & $2.5 \mathrm{a}$ & $56.0 \mathrm{~b}$ & $5.5 \mathrm{~b}$ \\
\hline 1988 & $0.5 \mathrm{c}$ & $50.0 \mathrm{~b}$ & $5.2 \mathrm{~b}$ \\
\hline \multicolumn{4}{|c|}{ Brodiaea laxa Queen Fabiola } \\
\hline 1986 & $1.3 \mathrm{~b}$ & $27.8 \mathrm{a}$ & $3.0 \mathrm{a}$ \\
\hline 1987 & $2.5 \mathrm{a}$ & $30.2 \mathrm{a}$ & $3.2 \mathrm{a}$ \\
\hline 1988 & $0.2 \mathrm{c}$ & $22.6 \mathrm{~b}$ & $3.0 \mathrm{a}$ \\
\hline \multicolumn{4}{|c|}{ Crocosmia $\times$ crocosmiiflora James Coey } \\
\hline 1986 & $0.9 \mathrm{~b}$ & $55.5 \mathrm{a}$ & $4.9 \mathrm{a}$ \\
\hline 1987 & $1.2 \mathrm{ab}$ & $40.1 \mathrm{~b}$ & $4.7 \mathrm{a}$ \\
\hline 1988 & 2.0 & $50.1 \mathrm{ab}$ & $4.5 \mathrm{a}$ \\
\hline
\end{tabular}

${ }^{2}$ Means within species and columns followed by the same letter are not significantly different using Tukey's test, $P=0.05$.

Table 4. Growth characteristics of 'De Caen' and 'Mona Lisa' anemone (1987 planting/1988 harvest).

\begin{tabular}{lcccc}
\hline \hline Cultivar & $\begin{array}{c}\text { Stems/ } \\
\text { corm }\end{array}$ & $\begin{array}{c}\text { Stem } \\
\text { length } \\
(\mathrm{cm})\end{array}$ & $\begin{array}{c}\text { Stem } \\
\text { diameter } \\
(\mathrm{mm})\end{array}$ & $\begin{array}{c}\text { Flower } \\
\text { diameter } \\
(\mathrm{cm})\end{array}$ \\
\hline De Caen & 7.5 & 24.7 & 5.4 & 3.9 \\
Mona Lisa & 6.5 & 30.0 & 6.4 & 4.8 \\
Significance & & & NS & $*$
\end{tabular}$*$\begin{tabular}{c}
$*$ \\
\hline
\end{tabular}

$\frac{\mathrm{NS},{ }^{*} \text { Nonsignificant or significant at } P=0.05 \text {, re- }}{}$ spectively, using $\mathrm{F}$ test.

similar in the 1987-88 study, However, flowering stems of 'Mona Lisa' were significantly longer and wider and had larger flowers than those of 'De Caen' (Table 4). 'Mona Lisa' flowered earlier and reached maximum yield 2 to 4 weeks after the beginning of harvest, while 'De Caen' reached maximum production 4 to 6 weeks after initial harvest (Fig. 1). These data suggest that 'De Caen' and 'Mona Lisa' could be planted together to extend anemone harvest period.

Allium sphaerocephalum. Stem diameter was $\approx 5 \%$ greater for flowers from the November planting, but no other significant differences occurred due to planting date (data not shown). Yield doubled in 1987 relative to 1986 , but stem length and diameter declined (Table 3). Numerous offsets were produced in Summer 1987 that likely contributed to the increase in yield and decrease in length and diameter. Although stems were shorter in 1987 that in 1986, no decline in quality was noted. Bulbs were decimated in 1988 by bulb rot (Sclerotium cepivorum), thus accounting for the low yield. De Hertogh (1989) suggested that this species is perennial in revised climatic zone 7; if disease pressure had not occurred, our study would presumably have confirmed his finding.

Brodiaea laxa. Corms planted in November produced fewer flowers, shorter stems, and flowered 1 week earlier than corms planted in December; otherwise, no trends emerged (Table 2). Brodea remained productive for 2 years, after which yield declined drastically (Table 3 ). The first harvest date and harvest duration in this study were similar to those obtained in Raleigh, N.C. (De Hertogh, 1989), but stems were shorter and plants could not be considered perennial.

Crocosmia. Yield and stem length were significantly greater for January-planted bulbs than for those planted in February or March (Table 2). Time to first harvest was extended by nearly 3 weeks for the March planting relative to the earliest planting. In England, Brown (1967) treated montbretia as a 2-year crop; however, corms in this study were productive for at least 3 years (Table 3 ). Yield increased each year, stem length showed no trend, and stem diameter was unaffected (Table 3). Analysis of harvest distribution for 1987 (Fig. 2) showed a peak yield 10 to 20 days after the start of harvest. Stem length was greatest at initial harvests but declined over time (Fig. 2)

Although field conditions vary widely in the United States, these data are useful for the field-grown specialty cut-flower grower. They provide guidelines for proper timing of selected bulbous species and demonstrate that extended planting techniques must be evaluated for each species and cultivar. The length of time bulbous species remain productive is also important for specialty cut-flower growers. These data suggest that certain species must be treated as annuals, whereas others may be productive for 2,3 , or more years if left undisturbed.

\section{Literature Cited}

Armitage, A.M. 1987. The influence of spacing on field-grown perennial crops. HortScience 22:904-907.

Brown, P.H. 1967. Flowers from-bulbs and corms. Min. of Agr., Fisheries and Food, \#197, Her Majesty's Stationery Office, London, U.K.

De Hertogh, A.A. 1989. Holland bulb forcer's guide. 4th ed. Intl. Flower Bulb Center, Hillegrom, The Netherlands.

Gill, L.M. 1979. The development and testing of the San Piran strain of Anemone. Annu. Rev. 1979 Rosewarne Expt. Hort. Sta. p. 8-12.

Horovitz, A. 1985. Anemone coronaria and related species, p. 455-464. In: A.H. Helevy (cd.). Handbook of flowering. vol. 1. CRC, Boca Raton, Fla.

Maia, N.P. and P. Vernard. 1974. La vernalization de bulbes d'anemones. P.H.M. Rev. Hort. 146:17-21

Rees, A.R. 1972. The growth of bulbs. Academic, London.

Rees, A.R. 1985a. Narcissus, p. 268-271. In: A.H. Helevy (cd.). Handbook of flowering. vol. 1. CRC, Boca Raton, Fla.

Rees, A.R. 1985b. Miscellaneous bulbs, p. 306308. In: A.H. Helevy (cd.). Handbook of flowering. vol. 1. CRC, Boca Raton, Fla.

Taylor, N. 1961. Taylor's encyclopedia of gardening. 4th ed. Houghton Mifflin, Boston.

Tompsett, L.A. 1980. Advancing and retarding flowering of Narcissus tazetta 'Grande Soleil D'Or'. Acts Hort. 100:57-62.

U.S. Department of Agriculture. 1990. USDA plant hardiness zone map. USDA Misc. Publ. 1475.

Wyman, D. 1971. Wyman's gardening encyclopedia. Macmillan, New York. 